\title{
MODEL KOOPERATIF TIPE TPS TERHADAP HASIL BELAJAR KONSEP PERKALIAN BILANGAN CACAH MATEMATIKA ANAK TUNARUNGU
}

\author{
Agnes Fitri Anjarsari dan Yuliati \\ Jurusan Pendidikan Luar Biasa Fakultas Ilmu Pendidikan Uniersitas Negeri Surabaya, \\ alovestory12@gmail.com 087703122244
}

\begin{abstract}
One of the deaf students disorders in mathematics lesson was their understanding toward the material of the concept of multiplication of numbers count mathematics so that it had less good impact to learning mathematics result. Based on the problem, this research applied cooperative learning of Think Pair Share (TPS) type with the purpose to analyze the influence of cooperative model of TPS type toward learning the concept of multiplication of numbers count mathematics result to hearing impairment students before and after going treatment.

The approach used was quantitative with pre-experiment kind and the design was one group pretest-posttest design. The data was collected by test method, observation, and documentation.

The results of data analysis, shows that the use of implementation influence of cooperative learning model of Think Pair Share (TPS) type approach significantly to learning the concept of multiplication of numbers count mathematics result to deaf students in SLB-B Dharma Wanita Sidoarjo.
\end{abstract}

Keywords: Think Pair Share (TPS), Learning Mathematics Result, Deaf

\section{PENDAHULUAN}

Anak tunarungu mengalami gangguan pada pendengarannya. Akibat dari kelainannya tersebut, perkembangan bahasanya menjadi terhambat, sehingga mereka kurang mampu bersosialisasi dengan masyarakat normal pada umumnya. Menurut Haenudin (2013:67) bahwa

"Anak Tunarungu dalam segi bicara dan bahasa mengalami hambatan, hal ini disebabkan adanya hubungan yang erat antara bahasa dan bicara dengan ketajaman pendengaran, mengingat bahasa dan bicara merupakan hasil proses peniruan sehingga para tunarungu dalam segi bahasa memiliki ciri yang khas, yaitu sangat terbatas dalam pemilihan kosa kata, sulit mengartikan arti kiasan dan kata-kata yang bersifat abstrak.”

Menurut Carmen Barajas, Antonia M. Gonzales-Cuenca, Francisco Carrero (2016) bahwa

"Introduction Mastery of reading is one of the fundamental core competencies of elementary education. Many research studies havedemonstrated that the reading performance of deaf students is significantly lower than that of their hearing peers .This remains true in spite of advances in audiology during the last 20 years, which have significantly improved the prognoses for development and learning in deaf students" 
Menurut Helen Blom, Eliane Segers, Daan Hermans, Harry Knoors, LudoVerhoeven (2017) bahwa

"Language and literacy development often go hand in hand; children with language problems are more likely to showreading-related difficulties as well. Studies show that spoken language development is affected in both D/HH children and children with SLI, but for different reasons. D/HH children show language problems due to their perceptual deficit, while children with SLI have cognitive difficulties processing incoming information in the brain"

Dapat disimpulkan bahwa keterampilan berbahasa anak normal diperoleh dari proses belajar bahasa dan bicara berdasarkan dari apa yang didengarnya. Sedangkan gangguan pendengaran anak tunarungu akan membawa dampak pada perkembangan berbahasanya yang mempengaruhi kemampuan berkomunikasi anak tunarungu.

Keterbatasan anak tunarungu dalam menerima informasi bersifat auditif menyebabkan perkembangan kognitif menjadi terhambat. Hambatan yang dialami anak tunarungu berakibat pada turunnya prestasi akademik yang mengakibatkan hasil belajar cenderung rendah, seperti pada bidang studi Matematika yang menuntut siswa untuk memiliki kemampuan berfikir abstrak. Hal tersebut menjadi kendala bagi anak tunarungu dalam memahami konsep matematika.

Menurut Douglass H. Clementsa, Karen C. Fusonb, Julie Saramaa (2017) bahwa

"We conclude that these criticisms are not valid, and that, given the importance of mathematics to academic success in all subjects, all children need and deserve to build a robust knowledge of mathematics in their earliest years and can do so if we use the research knowledge and research-based standards and programs presently available"

Dapat disimpulkan bahwa matematika merupakan ilmu yang sangat penting dalam membentuk pola pikir siswa, dalam matematika siswa dituntut harus memiliki kemampuan berpikir logis, analitis, sistematis, kritis dan kreatif. Salah satu tujuan pembelajaran matematika dalam Permendikbud nomor 24 tahun 2016 yaitu kurikulum 2013 terangkum dalam 4 (empat) Kompetensi Inti yaitu kompetensi sikap spiritual, kompetensi sikap sosial, kompetensi pengetahuan dan kompetensi ketrampilan. Kompetensi sikap spiritual Hal inilah pemahaman konsep memiliki peran yang penting bagi siswa dalam menyelesaikan permasalahan matematika.

Beth \& Piaget (1956) dalam Runtukahu, Tombokan, dan Kandou, Selpius, (2014:28) mengatakan bahwa yang dimaksud dengan matematika adalah pengetahuan yang berkaitan dengan berbagai unsur abstrak dan hubungan antar-struktur tersebut sehingga terorganisasi dengan baik. Sementara Kline (1972) dalam Runtukahu, Tombokan, dan Kandou, Selpius, (2014:28) lebih cenderung mengatakan bahwa matematika adalah pengetahuan yang tidak berdiri sendiri, tetapi 
dapat membantu manusia untuk memahami dan memecahkan permasalahan sosial, ekonomi dan alam. Di pihak lain, Reys (2002) dalam Runtukahu, Tombokan, dan Kandou, Selpius, (2014:28) mengatakan bahwa matematika adalah studi tentang pola dan hubungan cara berpikir dengan strategi organisasi, analisis dan sintesis, seni, bahasa,dan alat untuk memecahkan masalah-masalah abstrak dan praktis.

Dari paparan tersebut dapat disimpulkan bahwa pada dasarnya mata pelajaran matematika merupakan salah satu pembelajaran yang diajarkan bagi murid yang akan sangat bermanfaat bagi kehidupan sehari-hari. Pelajaran matematika dapat menunjang mata pelajaran yang lain. Namun dalam kenyataan di lapangan menunjukkan bahwa matematika dianggap sebagai salah satu mata pelajaran yang sulit dan sering menimbulkan masalah yang cukup berarti. Pembelajaran Matematika yang diterapkan bagi anak tunarungu mengacu pada Kurikulum 2013 (K13).

Berkaitan dengan pentingnya kebutuhan kurikulum dengan karakteristik anak tunarungu maka pemerintah Indonesia mengembangkan kurikulum terbaru yaitu Kurikulum 2013. Selain berbasis kompetensi juga berbasis karakter, Kurikulum 2013 juga memiliki beberapa karakteristikseperti yang tertulis dalam Peraturan Menteri Pendidikan dan Kebudayaan Nomor 67 Tahun 2013 Tentang Kerangka Dasar dan Struktur Kurikulum Sekolah Dasar/Madrasah Ibtidaiyah. Karakteristik kurikulum 2013 yaitu kurikulum yang mengakomodir keseimbangan antara aspek kompetensi sikap, ketrampilan, dan pengetahuan. Kompetensi dikembangkan melalui pembelajaran tematik terpadu.

Pembelajaran tematik/terpadu yang terdapat pada K13 juga merupakan suatu model pembelajaran yang memadukan beberapa materi pembelajaran dari berbagai kompetensi dasar dan kompetensi inti dari satu atau beberapa mata pelajaran khususnya pada pelajaran matematika dengan pelajaran yang lain untuk anak tunarungu. Salah satu penjabaran K13 pada mata pelajaran matematika adalah murid dapat melakukan operasi hitung campuran (penjumlahan, pengurangan, perkalian dan pembagian). Matematika memiliki cakupan yang lebih luas dari aritmatika. Aritmatika merupakan bagian dari matematika, kemampuan berhitung merupakan hal yang penting dan dapat memberikan manfaat dalam kehidupan semua orang dimasyarakat, termasuk anak tunarungu. Operasi hitung dalam bilangan adalah konsep aritmatika utama yang seharusnya dipelajari oleh anak-anak. Setelah mereka melakukan operasi penjumlahan dan pengurangan selanjutnya mereka mempelajari operasi bilangan perkalian dan pembagian. Yang menjadi kajian dalam penelitian ini adalah operasi hitung perkalian.

Perkalian merupakan operasi dasar aritmatika utama yang seharusnya dipelajari anak-anak setelah mereka mempelajari operasi penambahan dan pengurangan. Perkalian adalah penjumlahan 
berulang dengan angka yang sama. Operasi hitung perkalian terdapat pada pelajaran matematika yang diberikan disekolah tingkat sekolah dasar, termasuk disekolah luar biasa anak tunarungu.

Mencermati petingnya pengembangan dan pengoptimalan pemahaman konsep dalam pembelajaran matematika, maka perlu adanya upaya inovatif untuk menyelesaikan masalah tersebut yang dialami oleh anak tunarungu, terutama dalam berinteraksi sosial dan dapat meningkatkan hasil belajar perkalian matematika maka upaya yang dilakukan adalah dengan menerapkan model pembelajaran kooperatif. Sebab model pembelajaran kooperatif lebih menekankan kepada proses kerja sama dan saling berinteraksi dalam kelompok.

Menurut Arends (2007: 344)

"the cooperative learning model is characterized by cooperative task, goal, and reward structures. Students in cooperative learning situations are encoureged and/or required to work together on a common task, and they must coordinate their efforts to complete the task"

Dari paparan Arends dapat diartikan bahwa model pembelajaran kooperatif yaitu ditandai dengan tugas kooperatif, keberhasilan, dan reward. siswa dalam situasi pembelajaran kooperatif diperlukan bekerja sama dalam menyelesaikan tugas bersama, dan mereka harus mengkoordinasikan upaya mereka untuk menyelesaikan tugas.

Pembentukan kelompok didasarkan pada pemerataan karakteristik psikologis individu, yang meliputi kecerdasan, kecepatan belajar, motivasi belajar, perhatian, cara berpikir dan daya ingat.

Dari paparan tersebut dapat disimpulkan bahwa model pembelajaran kooperatif merupakan suatu model pembelajaran yang didalamnya siswa dengan karakteristik dan kemampuan berbeda dan saling bekerja sama menyelesaikan suatu masalah atau tugas pembelajaran. Dalam pembelajaran kooperatif tidak membedakan etnis, bahasa, dan jenis kelamin, kemampuan akademik, serta suku yang berbeda. Hal ini bertujuan untuk membangun tim belajar yang efektif.

Berdasarkan hasil observasi lapangan yang dijumpai pada anak tunarungu kelas III di SDLB-B Dharma Wanita Sidoarjo, terdapat 6 anak tunarungu yang mengalami kesulitan dalam menyelesaikan konsep perkalian bilangan cacah matematika. Selain itu proses pembelajaran yang sering diterapkan di Sekolah Luar Biasa berpusat pada guru. Hal ini dapat mempengaruhi prestasi belajar matematika pada anak tunarungu dalam memahami konsep perkalian bilangan cacah.

Memperhatikan masalah yang dihadapi anak tunarungu, maka guru perlu membuat model pembelajaran yang dapat menunjang kegiatan belajar mengajar di kelas. Sehingga anak tunarungu lebih mudah memahami operasi hitung perkalian bilangan cacah dengan hasil sampai 50 yang terdapat pada Kompetensi Dasar (KD) kelas III sekolah dasar anak tunarungu yaitu 4.3 menghitung operasi perkalian 2 bilangan satu angka dengan hasil sampai dengan 50 dibantu dengan media yang 
konkrit. Dari paparan tersebut dapat disimpulkan bahwa perkalian bilangan cacah dengan hasil sampai dengan 50 dengan menggunakan model pembelajaran kooperatif merupakan suatu model pembelajaran yang didalamnya siswa dengan karaktersitik dan kemampuan yang berbeda saling berkerja sama menyelesaikan masalah atau tugas pembelajaran. Salah satu model pembelajaran yang dapat diterapkan bagi anak tunarungu adalah melalui model pembelajaran kooperatif tipe Think Pair Share (TPS) yang dikembangkan oleh Frank Lyman.

Menurut Arends (2007: 354) “The particular approach describe here, initially developed by Frank Lyman (1985) and his collagues at the University of Maryland, is an effective way to change to discourse pattern in class room"

Dari paparan Arends dapat diartikan bahwa Think Pair Share pertama kali dikembangkan oleh Franklyman, dan kolegannya di Universitas Marryland pada tahun 1985. Mereka menyatakan bahwa Think Pair Share merupakan suatu cara yang efektif untuk mengganti suasana pola diskusi kelas.

Dengan asumsi bahwa dalam model pembelajaran kooperatif tipe Think Pair Share memberi siswa waktu yang lebih banyak untuk berfikir, meserpon dan saling berkerja sama dengan teman dalam kelompoknya. Model pembelajaran Think Pair Share bersesuaian dengan langkah pendekatan saintifik seperti yang diterapkan pada kurikulum 2013, karena proses-proses dalam pendekatan saintifik dapat diimplikasikan pada fase-fase TPS. Proses mengamati dalam pendekatan saintifik bisa teraplikasi dalam fase Think dalam model TPS, yaitu pada saat demonstrasi dan pengerjaan TPS secara mendiri. Proses menanya, bisa teraplikasi dalam fase Pair (diskusi berpasangan) dan fase Share (diskusi kelas). Proses mengumpulkan informasi dapat ditemukan dalam fase think, pair maupun share. Proses mengumpulkan informasi dapat ditemukan pada semua fase dalam TPS. Proses mengkomunikasikan dalam pendekatan saintifik, nampak pada fase pair dan share.

Hasil penelitian Azizah yang berjudul "Pengaruh Model Pembelajaran Kooperatif Tipe Think Pair Share Terhadap Aktivitas Siswa dan Hasil Belajar Matematika Anak Tunarungu" mengungkapkan bahwa ada pengaruh yang signifikan terhadap aktivitas siswa dan hasil belajar matematika anak tunarungu kelas IV di SDLB-B Karya Mulia I Surabaya setelah dilakukan intervensi dengan menggunakan penggunaan model pembelajaran kooperatif tipe Think Pair Share yang menunjukkan adanya perubahan yang lebih baik dari hasil pre test ke post test. Hal ini sejalan dengan teori yang dikemukakan oleh Slavin (2005: 33) mengemukakan bahwa "penelitian mengenai pembelajaran kooperatif telah memperlihatkan bagaimana strategi ini bisa mengembangkan pencapaian yang bisa dibuat para siswa". 
Dalam kajian pada penelitian ini menggunakan model pembelajaran kooperatif tipe Think Pair Share sebagai upaya peningkatan terhadap hasil belajar konsep perkalian bilangan cacah matematika anak tunarungu.

Menurut Arends (2007: 354) menyatakan bahwa “...and it has build-in procedures for giving students more time to think and to respond and to help each other". Dari paparan Arends dapat diartikan yaitu prosedur yang digunakan dalam Think-Pair-Share dapat memberikan banyak waktu bagi siswa lainnya untuk berpikir, merespons, dan saling membantu.

Dengan asumsi bahwa dengan menerapkan model pembelajaran kooperatif tipe Think-PairShare dapat memberikan pengalaman saling berinteraksi dan bekerja sama antar anggota kelompok dalam menyelesaikan suatu permasalahan dari apa yang dipelajari oleh siswa tunarungu.

Akhirnya berdasarkan latar belakang dan alasan di atas peneliti ingin mralukan penelitian yang berjudul "Pengaruh Model Kooperatif Tipe TPS Terhadap Hasil Belajar Konsep Perkalian Bilangan Cacah Matematika Anak Tunarungu.”

\section{METODE}

Desain penelitian yang digunakan dalam penelitian ini adalah pra-eksperimen dengan bentuk “one group pre-test post-tes design”yang melibatkan satu kelompok .

\section{Variabel}

\section{- Variabel Bebas}

Variabel bebas pada penelitian ini adalah model kooperatif tipe TPS

\section{- Variabel Terikat}

Variabel terikat pada penelitian ini adalah hasil belajar konsep perkalian bilangan cacah matematika

\section{Subjek Penelitian}

Subjek dalam penelitian ini adalah 6 anak tunarungu yang hasil belajar konsep perkalian masih kurang.

Tabel 3.1. Subjek Penelitian

\begin{tabular}{|c|l|l|}
\hline Nomor & \multicolumn{1}{|c|}{ Nama } & \multicolumn{1}{c|}{ Jenis Kelamin } \\
\hline 1 & DRB & Laki-laki \\
\hline 2 & ASA & Laki-laki \\
\hline 3 & BA & Laki-laki \\
\hline 4 & ANK & Perempuan \\
\hline 5 & VAN & Perempuan \\
\hline 6 & PPM & Perempuan \\
\hline
\end{tabular}




\section{Definisi Operasional}

- Model Pembelajaran TPS

Pendekatan Model pembelajaran kooperatif tipe Think Pair Share yang dimaksud dalam penelitian ini adalah belajar secara berpasangan dengan memberikan siswa lebih banyak waktu untuk berpikir, merespons dan saling membantu. Pelasanaan model pembelajaran kooperatif tipe Think Pair Share (TPS) terdiri dari 3 fase, yaitu: thinking (berpikir), pairing (berpasangan), sharing (berbagi)

- Hasil Belajar Matematika

Hasil belajar matematika anak tunarungu dalam penelitian ini berdasarkan selisih atau perbedaan antara nilai pre test dan nilai post test. Nilai pre test sebelum diberikan perlakuan penerapan model pembelajaran kooperatif tipe Think Pair Share dan nilai post test yaitu setelah diberikan perlakuan dengan menerapkan model pembeljaran kooperatif tipe Think Pair Share.

- Anak Tunarungu

Anak tunarungu adalah anak yang mengalami gangguan dalam hal pendengaran sehingga memerlukan layana dan pendidikan khusus. Siswa tunarungu dalam penelitian ini adalah siswa yang berada di kelas III SLB-B Dharma Wanita Sidoarjo yang dijadikan subjek penelitian. Subjek yang diteliti sejumlah 6 siswa tunarungu di SLB-B Dharma Wanita Sidoarjo.

\section{Prosedur Penelitian}

- Memberikan pre-test

Pre-test dilakukan untuk mengetahui hasil belajar konsep perkalian bilangan cacah matematika sebelum diterapkan model kooperatif tipe TPS.

- Memberikan perlakuan.

Pemberian perlakuan yang dilakukan ntuk mengembangkan kemampuan berhitung pada konsep perkalian bilangan cacah matematika menggunakan model pembelajaran kooperatif tipe TPS kepada siswa tunarungu kelas III SLB-B Dharma Wanita Sidoarjo. Pemberian intervensi dilakukan sebanyak 6 kali pertemuan dengan wantu 2 x 30 menit.

- Memberikan post-test

Post-test dulakukan untuk mengetahui hasil belajar konsep perkalian bilangan cacah matematika setelah diterapkan model kooperatif tipe TPS.

\section{Teknik Pengumpulan Data}

Teknik pengumpulan data yang digunakan peneliti adalah, metode tes, dan metode observasi. Adapun tes yang dimaksudkan dalam penelitian ini ada dua yakni pre-test dan post-test. Pre-test 
diberikan untuk mengetahui kemampuan berhitung konsep perkalian bilangan cacah matematika sebelum diberikan perlakuan. Sedangkan post-test diberikan untuk mengetahui kemampuan berhitung konsep perkalian bilangan cacah matematika setelah diberi perlakuan.

Metode observasi yang digunakan dalam penelitian ini bertujuan untuk memperoleh data yang aktual mengenai perhatian siswa terhadap materi yang disampaikan guru, kecakapan dalam berkomunikasi, kemandirian dalam menyelesaikan tugas, kemampuan bekerjasama dengan kelompok, keaktifan dalam menyampaikan pendapat, penguasaan materi yang disampaikan oleh guru, dan ketepatan dalam menemukan jawaban soal yang diberikan guru. Untuk mendapatkan data yaitu dengan cara membuat catatan perkembangan siswa selama penelitian berlangsung dengan menggunakan pedoman observasi

\section{Teknik Analisis Data}

Teknik analisis data pada penelitian ini menggunakan rumus wilcoxon match pairs test dengan rumus sebagai berikut:

sedikit, dengan rumus sebagai berikut:

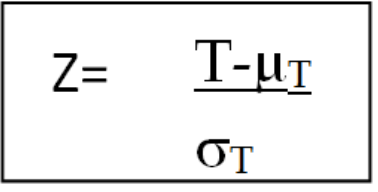

Keterangan:

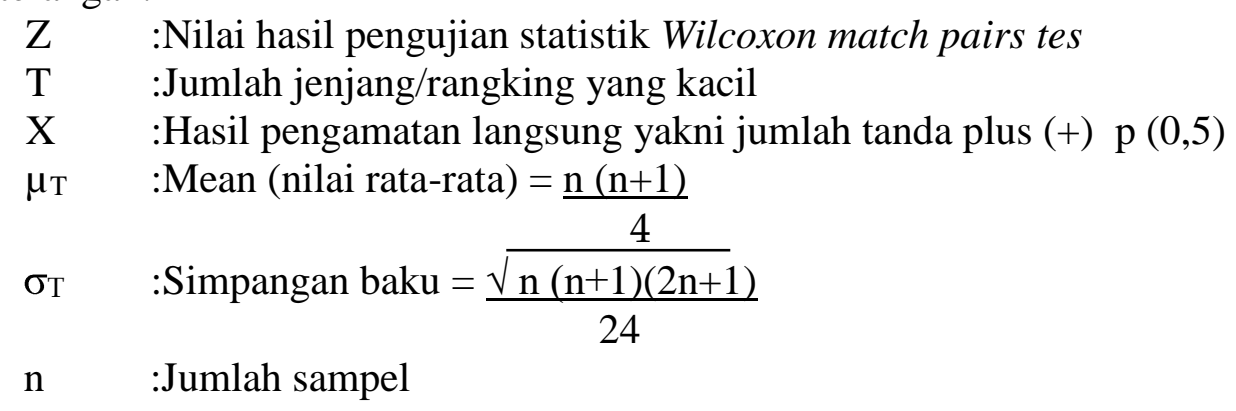

\section{Intepretasi Hasil Analisis Data}

- Jika $\mathrm{Z}$ hitung $(\mathrm{Zh}) \leq \mathrm{Z}$ tabel $(\mathrm{Zt})$ maka Ho diterima, berarti tidak ada pengaruh yang signifikan pada penggunaan tipe Think Pair Share (TPS) terhadap hasil belajar konsep perkalian bilangan cacah matematika anak tunarungu di SLB-B Dharma Wanita Sidoarjo

- Jika $\mathrm{Z}$ hitung $(\mathrm{Zh}) \geq \mathrm{Z}$ tabel $(\mathrm{Zt})$ maka Ho ditolak, berarti ada pengaruh yang signifikan pada penggunaan tipe Think Pair Share (TPS) terhadap hasil belajar konsep perkalian bilangan cacah matematika anak tunarungu di SLB-B Dharma Wanita Sidoarjo 


\section{HASIL DAN PEMBAHASAN}

\section{Hasil Penelitian}

Pre-test dilakukan untuk mengetahui hasil belajar konsep perkalian bilangan cacah matematika sebelum diterapkan model kooperatif tipe Think Pair Share (TPS) pada siswa tunarungu kelas III SLB-B Dharma Wanita Sidoarjo.

\section{Tabel 4.1}

\section{Data pre-test hasil belajar matematika sebelum diterapkan model pembelajaran TPS}

\begin{tabular}{|c|c|}
\hline Nama & Hasil Pre test anak \\
\hline DRB & 40 \\
\hline ASA & 55 \\
\hline BA & 55 \\
\hline ANK & 30 \\
\hline VAN & 50 \\
\hline PPM & 55 \\
\hline Rata-Rata & 47,5 \\
\hline
\end{tabular}

Post-test dilakukan untuk mengatahui hasil belajar konsep perkalian bilangan cacah matematika setelah diterapkan model kooperatif tipe Think Pair Share (TPS) pada siswa tunarungu kelas III SLB-B Dharma Wanita Sidoarjo.

Tabel 4.2

Data post-test hasil belajar matematika sesudah diterapkan model pembelajaran TPS

\begin{tabular}{|c|c|}
\hline Nama & Hasil Pre test anak \\
\hline DRB & 70 \\
\hline ASA & 100 \\
\hline BA & 100 \\
\hline ANK & 100 \\
\hline VAN & 85 \\
\hline PPM & 100 \\
\hline Rata-Rata & 92,5 \\
\hline
\end{tabular}

Rekapitulasi dimaksudkan untuk mengetahui perbandingan hasil belajar pemecahan soal konsep perkalian bilangan cacah matematika anak tunarungu dengan menggunakan model pembelajaran think pair share (TPS) pada anak tunarungu kelas III di SLB-B Dharma Wanita Sidoarjo sebelum diberi perlakuan dan sesudah diberi perlakuan menggunakan model TPS. Sehingga dapat diketahui ada pengaruh atau tidak ada pengaruh penggunaan model pembelajaran kooperatif tipe Think Pair Share (TPS) terhadap hasil belajar konsep perkalian bilangan cacah anak tunarungu kelas III di SLB-B Dharma Wanita Sidoarjo. Adapun hasil rekapitulasi pre-test dan posttest. 
Tabel 4.3

Hasil rekapitulasi data hasil belajar matematika sebelum dan sesudah diberikan perlakuan dengan menggunakan model pembelajaran TPS

\begin{tabular}{|c|c|c|c|}
\hline No & Nama & Pre-test & Post-Test \\
\hline 1 & DRB & 40 & 70 \\
\hline 2 & ASA & 55 & 100 \\
\hline 3 & BA & 55 & 100 \\
\hline 4 & ANK & 30 & 100 \\
\hline 5 & VAN & 50 & 85 \\
\hline 6 & PPM & 55 & 100 \\
\hline \multicolumn{2}{|c|}{ Rata-Rata Nilai } & 47,5 & 92,5 \\
\hline
\end{tabular}

Data hasil pre-test dan post-test dianalisis menggunakan statistik non parametrik dengan menggunakan rumus wilcoxon match pairs test.

Tabel 4.4

Tabel penolong uji Wilcoxon hasil belajar konsep perkalian bilangan cacah anak tunarungu sebelum dan sesudah menggunakan model TPS

\begin{tabular}{|c|c|c|c|c|c|c|}
\hline \multirow{2}{*}{ Subyek } & Pre & Post & \multirow{2}{*}{$\begin{array}{c}\text { Test } \\
\text { Test }\end{array}$} & Beda & \multicolumn{3}{|c|}{ Tanda Jenjang } \\
\cline { 5 - 7 } & $(\mathrm{O} 2)$ & & Jenjang & + & - \\
\hline DRB & 40 & 70 & 30 & 1 & +1 & 0 \\
\hline ASA & 55 & 100 & 45 & 4 & +4 & 0 \\
\hline BA & 55 & 100 & 45 & 4 & +4 & 0 \\
\hline ANK & 30 & 100 & 70 & 6 & +6 & 0 \\
\hline VAN & 50 & 85 & 35 & 2 & +2 & 0 \\
\hline PPM & 55 & 100 & 45 & 4 & +4 & 0 \\
\hline \multicolumn{3}{|c|}{ Jumlah } \\
\hline
\end{tabular}

Data-data dalam tabel kerja perubahan diatas diolah melalui teknik analisis data dengan menggunakan wilcoxon match pairs test:

$$
\mathrm{Z}=\frac{\mathrm{T}-\underline{\mu}_{\mathrm{T}}}{\sigma_{\mathrm{T}}}
$$

Keterangan:

$\mathrm{Z} \quad$ :Nilai hasil pengujian statistik Wilcoxon match pairs tes

$\mathrm{T} \quad$ :Jumlah jenjang/rangking yang kacil

$\mathrm{X} \quad$ :Hasil pengamatan langsung yakni jumlah tanda plus (+) $\mathrm{p}(0,5)$

$\mu_{\mathrm{T}} \quad:$ Mean $($ nilai rata-rata $)=\underline{\mathrm{n}(\mathrm{n}+1)}$

$\sigma_{\mathrm{T}} \quad:$ Simpangan baku $=\underline{\sqrt{\mathrm{n}(\mathrm{n}+1)(2 \mathrm{n}+1)}}$ 
n : :Jumlah sampel

p :Probabilitas untuk memperoleh tanda $(+)$ dan $(-)=0,5$ karena nilai kritis 5\%

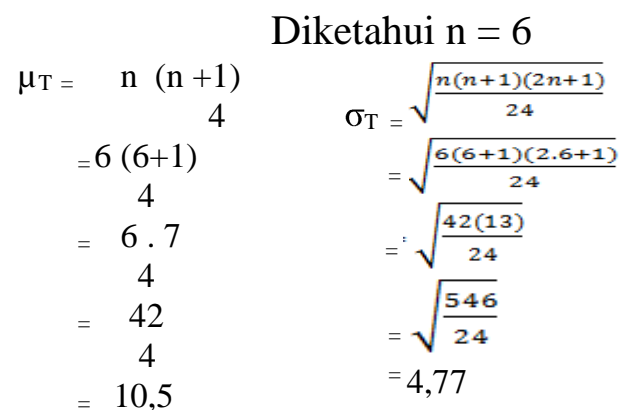

Mean $(\mu \mathrm{T})$ dan simpangan baku $\left(\sigma_{\mathrm{T}}\right)$ dimasukkan ke dalam rumus uji Wilcoxon pairs match:

$$
\begin{aligned}
Z & =\frac{T-\mu_{T}}{\sigma_{T}} \\
& =\frac{T-\frac{n(n+1)}{4}}{\sqrt{\frac{n(n+1)(2 n+1)}{24}}} \\
& =\frac{0-10,5}{4,77} \\
& =-2,20 \\
& =2,20
\end{aligned}
$$

Hasil analisis data yang digunakan peneliti adalah statistik non parametrik dengan rumus uji wilcoxon match pairs test, karena data bersifat kuantitatif dalam bentuk angka, serta jumlah subjek yang digunakan yaitu < 30 sampel. Penelitian ini menggunakan nilai kritis 5\% yang berarti, tingkat kesalahan pada peneltian ini adalah 5\% sehingga tingkat kebenaran dalam penelitian ini sebesar 95\%. Hal ini berarti tingkat kepercayaan hasil analisis data yang dilakukan pada penelitian ini sebesar 95\%. Nilai $\mathrm{Z}$ tabel dengan nilai kritis 5\% (untuk pengujian dua sisi) $=1,96$, diperoleh $\mathrm{Z}$ hitung $(2,521)>\mathrm{Z}$ tabel $(1,96)$ sehingga hipotetsis kerja (Ha) diterima dan hipotesis nol (Ho) ditolak. Ketika Ha diterima berarti, terdapat pengaruh yang signifikan penggunaan model kooperatif tipe TPS terhadap hasil belajar konsep perkalian bilangan cacah matematika anak tunarungu kelas III di SLB-B Dharma Wanita Sidoarjo.

\section{Hasil Aktivitas Belajar Siswa}

Hasil aktivitas belajar siswa yang dievaluasi pada penelitian ini adalah perhatian terhadap materi yang disampaikan, kerjasama dalam kelompok, penguasaan terhadap materi, keaktifan dalam menyampaikan pendapat, tanggungjawab didalam kelompok, serta kecakapan komunikasi dalam 
kelompok. Berikut akan diuraikan evaluasi aktivitas belajar siswa selama $6 \mathrm{x}$ pertemuan pada treatment.

Tabel 4.5

Tabel rekapitulasi lembar aktivitas belajar siswa penerapan model pembelajaran kooperatif tipe Think Pair Share (TPS)

\begin{tabular}{|c|c|c|c|c|c|}
\hline \multirow{2}{*}{ Pertemuan } & \multicolumn{5}{|c|}{ Aspek } \\
\cline { 2 - 6 } & Perhatian & Kerjasama & $\begin{array}{c}\text { Penguasaan } \\
\text { Materi }\end{array}$ & Keaktifan & $\begin{array}{c}\text { Tanggung } \\
\text { Jawab }\end{array}$ \\
\hline Pertemuan 1 & & & & $83 \%$ & $83 \%$ \\
\hline Pertemuan 2 & & & & & \\
\hline Pertemuan 3 & & $83 \%$ & & & \\
\hline Pertemuan 4 & $66 \%$ & & & & \\
\hline Pertemuan 5 & $83 \%$ & & $66 \%$ & & \\
\hline Pertemuan 6 & & & & & \\
\hline
\end{tabular}

Berdasarkan rekapitulasi tabel pada lembar aktivitas belajar siswa yang dilaksanakan pada saat treatment, maka dapat diuraikan bahwa pada pertemuan 1, didominasi oleh aspek keaktifan siswa $83 \%$, pertemuan 2 didominasi oleh aspek tanggung jawab 83\%, pertemuan 3 didominasi oleh aspek kerjasama 83\%, pertemuan 4 didominasi perhatian 66\%, pertemuan 5 didominasi perhatian $83 \%$, pertemuan 6 didominasi penguasaan materi 66\%. Sehingga dapat dihitung rata-rata keberhasilan model pembelajaran kooperatif tipe Think Pair Share (TPS) adalah

\section{Pembahasan}

\section{Hasil Belajar Siswa}

Berdasarkan hasil analisis data yang diperoleh hasil $\mathrm{Z}$ hitung 2,20 dengan perbandingan $\mathrm{Z}$ tabel pada nilai kritis 5\%, berarti tingkat kepercayaan hasil analisis data sebesar 95\%. Makna dari hasil analisis tersebut adalah bahwa tingkat keberhasilan model kooperatif tipe TPS terhadap hasil belajar konsep perkalian bilangan cacah matematika tingkat keberhasilan mencapai 95\%, sedangkan tingkat kegagalan hanya 5\%.

Penelitian ini menunjang teori Bruner yang mengatakan bahwa tahapan belajar sesuai perkembangan kognitif bermula dengan pembelajaran enaktif atau konkret, kemudian ikonik atau semi konkret serta simbolik atau abstrak (Suyono dan Hariyanto, 2015). Pembelajaran secara konkret pada penelitian ini sangat berkalitan dengan pembelajaran matematika yang menggunakan media-media visual secara konkret saat pembelajarannya. Media yang digunakan dalam penelitian ini seperti, keriki congklak, bola tangan, dan karet lompat tali yang sengaja dihadirkan untuk mempermudah dalam proses pembelajaran, dengan adanya media yang 
disediakan anak mampu mengamati serta mencoba langsung secara individu maupun kelompok dalam perkalian bilangan cacah matematika dengan hasil sampai 50. Ketika anak paham dalam konsep perkalian yang diajarkan maka pada penelitian ini anak dengan mudah memecahkan masalah dalam konsep perkalian bilangan cacah matematika.

Edgar Dale memaparkan hasil temuan penelitiannya yang berupa persentase ingatan terhadap pembelajaran yang dilakukan yaitu, melalui ceramah kemampuan mengingat anak sebesar 20\%, melalui tertulis (membaca) kemampuan mengingat anak sebesar $72 \%$, melalui visual dan verbal (pengajaran melalui ilustrasi) diperoleh persentase mengingat anak sebesar 80\%, serta melalui partisipatori (bermain peran, studi kasus, praktek) sebesar 90\% (Warsono dan Hariyanto, 2012).

Hasil belajar konsep perkalian bilangan cacah anak tunarungu yang diperoleh anak tunarungu dengan menerapkan model pembelajaran kooperatif tipe Think Pair Share (TPS). Sebagaimana dikemukakan oleh Slavin, R (2005: 4) bahwa pembelajaran kooperatif merujuk pada berbagai macam metode pengajaran dimana para siswa bekerja dalam kelompok-kelompok kecil untuk saling membantu satu sama lainnya dalam mempelajari materi pelajaran. Sedangkan Think Pair Share (TPS) merupakan suatu cara yang efektif untuk membuat variasi suasana pola diskusi kelas, yang dikemukakan oleh Arends (2007: 354).

Pada pelaksanaan penerapan model kooperatif tipe Think Pair Share (TPS) memperkuat penyampaian materi dan membangun pengetahuan ataupun konsep dengan memberikan

$$
\frac{83 \%+83 \%+83 \%+66 \%+83 \%+66 \%}{5}=92,8
$$

pengalaman konkrit kepada siswa mengenai hal-hal yang abstrak, seperti pemahaman dalam konsep perkalian bilangan cacah matematika untuk anak tunarungu. Sejalan dengan teori Franklyman yang mengatakan bahwa prosedur yang digunakan dalam Think-Pair-Share dapat memberikan banyak waktu bagi siswa lainnya untuk berpikir, merespons, dan saling membantu. ( Arends 2007: 354). Melalui model pembelajaran kooperatif tipe Think Pair Share (TPS) siswa juga dapat mengembangkan hubungan antar kelompok, penerimaan terhadap teman sekelas yang lemah dalam bidang akademik, meningkatkan rasa percaya diri, meningkatkan rasa harga diri, serta tumbuhnya kesadaran bahwa siswa perlu belajar untuk berpikir, menyelesaikan masalah dan mengintegrasikan serta mengaplikasikan kemampuan dan pengetahuan mereka, Slavin. R (2005: 5).

Penggunaan model kooperatif tipe Think Pair Share (TPS) dalam pembelajaran matematika didukung penelitian terdahulu dengan hasil model kooperatif tipe Think Pair Share (TPS) ini 
terbuki lebih efektif dalam pengajaran anak tunarungu terutama pembelajaran matriks matematika (Azizah, Nur, 2008).

Berdasarkan hasil penelitian yang telah dilakukan dapat menjawab rumusan masalah bahwa ada pengaruh model pembelajaran kooperatif tipe Think Pair Share (TPS) terhadap hasil belajar konsep perkalian bilangan cacah anak tunarungu di SLB-B Dharma Wanita Sidoarjo sehingga Think Pair Share (TPS) dapat diimplementasikan pada mata pelajaran matematika materi perkalian bilangan cacah anak tunarungu.

\section{Hasil Pengamatan Aktivitas Belajar Siswa}

Think Pair Share ini berkembang dari penelitian belajar kooperatif dan waktu tunggu. Pertama kali dikembangkan oleh Frank Lyman dan Koleganya di Universitas Maryland pada tahun 1981. Menurut Arends (2007: 354) menyatakan bahwa “...and it has build-in procedures for giving students more time to think and to respond and to help each other". Analisis data berdasarkan hasil pengamatan pelaksanaan kooperatif tipe Think Pair Share (TPS) pada pertemuan awal, yaitu berdasarkan tabel 4.6 tentang evaluasi aktivitas belajar siswa pelaksanaan treatment ke satu diperoleh hasil bahwa perhatian siswa terhadap materi, kerjasama, serta tanggungjawab di dalam kelompok masih rendah. Hal ini didukung oleh teori Arends (2007: 344) Rendahnya perhatian, kerjasama, dan tanggung jawab dalam kelompok tersebut, dilatarbelakangi oleh proses belajar mengajar yang dilakukan sebelum adanya perlakuan atau treatment dengan menggunakan model pembelajaran kooperatif tipe Think Pair Share (TPS) adalah dengan ceramah. Sebagai akibat dari ketunarunguan juga mempengaruhi aktivitas belajar siswa dengan menggunakan model pembelajaran kooperatif tipe Think Pair Share (TPS).

Selanjutnya, dalam pelaksanaan perlakuan atau treatment. Diperoleh hasil bahwa siswa mengalami perkembangan yang sangat signifikan dalam aspek kerjasama dalam kelompok, yang terjadi pada treatment ke 3. Sedangkan pada treatment ke 1 aspek yang menonjol adalah keaktifan, treatment ke 2 aspek yang menonjol adalah tanggungjawab, treatment ke 4 dan 5 aspek yang menonjol adalah perhatian, treatment ke 6 aspek yang menonjol adalah penguasaan materi. Akumulasi dari aktivitas belajar siswa diperoleh hasil 92,8 yang menyatakan bahwa penggunaan model kooperatif tipe Think Pair Share (TPS) pada mata pelajaran matematika materi konsep perkalian bilangan cacah anak tunarungu adalah sangat baik. 


\section{PENUTUP}

\section{Simpulan}

Berdasarkan hasil analisis uji wilcoxon tentang hasil belajar konsep perjalian bilangan cacah matematika pada anak tunarungu kelas III di SLB-B Dharma Wanita Sidoarjo,, diketahui Z hitung 2,o lebih besar dari pada nilai $\mathrm{Z}$ tabel dengan nilai kritis $5 \%$ ( uji dua sisi ) $=1,96$ sehingga hipotesis nol (Ho) ditolak dan hipotesis kerja (Ha) diterima. Hasil analisis tersebut dapat membuktikan bahwa ada pengaruh yang signifikan pada model kooperatif tipe Think Pair Share (TPS) terhadap hasil belajar konsep perkalian bilangan cacah matematika anak tunarungu kelas III di SLb-B Dharma Wanita Sidoarjo.

Berdasarkan analisis data pada lembar aktivitas belajar siswa pelaksanaan treatment menggunakan model pembelajaran kooperatif tipe Think Pair Share (TPS) adalah sangat baik dari aspek perhatian, kerjasama, penguasaan materi, keaktifan, dan tanggung jawab dengan rata-rata perolehan presentase sebesar $92,8 \%$.

\section{Saran}

Berdasarkan simpulan di atas, maka dapat diberikan saran:

- Bagi guru, agar implementasi model pembelajaran kooperatif tipe Think Pair Share (TPS) dapat terlaksana dengan baik, maka dalam pelaksanaannya perlu diperhatikan karakteristik siswa. Karakteristik siswa perlu diperhatikan karena untuk memaksimalkan implementasi model pembelajaran kooperatif tipe Think Pair Share (TPS). Sehingga diperlukan upaya untuk membantu kesiapan belajar siswa, diantaranya: pada pembagian kelompok, pengaturan kelompok dan tempat duduk tersebut dimaksudkan untuk memudahkan dalam aktivitas belajar siswa sekaligus memudahkan siswa untuk dalam pencapaian hasil belajar, dikarenakan terdapat timbal balik positif antara siswa yang memiliki kognisi yang tinggi dan siswa yang memiliki kognisi yang rendah, serta penggunaan media yang konkrit dan menarik dapat menambah pencapaian hasil belajar. Hasil penelitian ini dapat dijadikan sebagai salah satu alternative untuk mengajarkan konsep perkalian bilangan cacah menggunakan model pembelajaran TPS, karena dengan menggunakan model pembelajaran ini memberikan kesempatan siswa untuk lebih aktif dalam proses pembelajaran pada siswa tunarungu

- Bagi peneliti selanjutnya, penelitian ini dapat dijadikan pijakan berpikir untuk melakukan penelitian yang terkait serta dapat dijadikan referensi sebagai bahan kajian penelitian selanjutnya. 


\section{DAFTAR PUSTAKA}

Amri, Sofan. 2013. Pengembangan \& Model Pembelajaran dalam Kurikulum 2013. Jakarta : PT. Prestasi Putrakaraya.

Arends, I. Richard. 2007.Learning to Teach. Seventh Edition. New York : The McGraw-Hill Companies, Inc.

Arikunto, S. 2010. Prosedur Penelitian Suatu Pendekatan Praktik. Jakarta: Rineka Cipta.

Azizah, Nur.2008. "Pengaruh Model Pembelajran Kooperatif Tipe Think Pair Share Terhadap Aktivitas Siswa Dan Hasil Belajar Matematika Anak Tunarungu". Kampus PLB FIP UNESA: Jurnal Pendidikan Luar Biasa, Volume 4, Nomor 1. Surabaya : Himpunan Sarjana Pendidikan Luar Biasa (HISPELBI)

Bunawan, Lani dan Yuwati, C.S. 2000. Penguasaan Bahasa Anak Tunarungu. Jakarta: Yayasan Santi Rama.

Carmen Barajas, Antonia M. Gonzales-Cuenca, Francisco Carrero, 2016. "Comprehension of texts by deaf elementary school students: The role of grammatical understanding. International Journal Educational Research". Research in Developmental Disabilities 58 (2016) 8-23

Charitas, Indah Permana Rully, dkk. 2015. Mengenal Matematika Lebih Dekat. Yogyakarta: Matematika

Delphie, Bandi. 2009. Matematika untuk Anak Berkebutuhan Khusus. Sleman: PT. Intan Sejati Klaten.

Douglas H. Clementsa, Karen C. Fusonb, Julie Saramaa. 2017. "The research-based balance in early childhood mathematics: A response to Common Core criticisms". International Journal Educational Research.Early Childhood Research Quarterly

Haenudin. 2013. Pendidikan Anak Berkebutuhan Khusus Tunarungu . Jakarta Timur : PT. Luxima Metro Media.

Hajar, Ibnu. 2013. Panduan Lengkap Kurikulum Tematik. Jogjakarta: DIVA Press

Hartono, Rudi. 2013. Ragam Model Mengajar yang Mudah Diterima Murid. Jogjakarta : DIVA Press.

Hartono, Wahyudi dan Samiadi, Novita Nur. "Urgensi Pembelajaran Perkalian Bilangan dengan Pendekatan Matematika Realistik Indonesia untuk Meningkatkan Prestasi Belajar Matematika pada Siswa Tunarungu”. Jurnal Pendidikan Luar Biasa, Volume 4, Nomor 1. Surabaya : Himpunan Sarjana Pendidikan Luar Biasa (HISPELBI)

Helen Blom, Eliane Segers, Daan Hermans, Harry Knoors, Ludo Verhoeven. 2017. "Hypertext comprehension of deaf and hard-of-hearing students and students with specific language impaiment. International Journal Educational Research". Research in Developmental Disabilities 61 (2017) 127-137. 
Heruman. 2014. Model Pembelajaran Matematika Di Sekolah Dasar. Bandung: PT Remaja Rosdakarya.

Marc Marschark, Carolyn Morrison, Jennifer Lukomski, Georgina Borgna, Carol Convenrtino. 2013. “Are deaf students visual learners?". International Journal Educational Research. Learning and Individual Difference.

Marina Supanc, Vanessa A. V Ollinger, Joachim C. Brunstein. 2017. "High-structure versus lowstructure cooperative learning in introductory psychology classes for student teachers: Effects on conceptual knowledge, self-perceived competence, and subjective task value". International Journal Educational Research. Learning and Instruction.

Mufidah, Lailatul, Effendi, Dzulkifli dan Purwanti, Titi Teri. 2013. "Penerapan Model Pembelajaran Kooperatif Tipe TPS Untuk Meningkatkan Aktivitas Belajar Siswa Pada Pokok Bahasan Matriks". Jurnal Pendidikan Matematika STKIP PGRI Sidoarjo. Vol I (1): hal 1-9

Muhsetyo, Gatot. 2010. Pembelajaran Matematika SD. Jakarta: Universitas Terbuka

Nataliasari, Ike. 2014. "Penggunaan Model Pembelajaran Kooperatif Tipe Think Pair Share (TPS) Meningkatkan Kemampuan Penalaran dan Pemecahan Masalah Matematis Siswa MTS". Jurnal Pendidikan dan Keguruan. Vol I. (1) artikel 3

Ni'mah, Dwijananti. 2014. "Penerapan Model Pembelajaran Think Pair Share (TPS) Dengan Metode Eksperimen untuk Meningkatkan Hasil Belajar dan Aktivitas Belajar Siswa Kelas VIII MTs. Nahdlatul Muslimin Kudus". Unnes Physics Education Journal: hal 1-8

Rahmi, Halfi. 2012. "Meningkatkan Kemampuan Pengoperasian Perkalian Melalui Metode Horizontal Bagi Anak Tunarungu”. Jurnal Ilmiah Pendidikan Khusus. Volume 1 Nomor 2.

Rosita dan Leonard. "Meningkatkan Kerja Sama Siswa Melalui Pembelajaran Kooperatif Tipe Think Pair Share”. Jurnal Formatif. Vol III. (1): hal 1-10

Runtuahu, Tombokan dan kandou, Selpius. 2014. Pembelajaran Matematika Dasar Bagi Anak Berkesulitan Belajar. Yogyakarta: Ar-Ruzz Media.

Slavin, E. Robert . 2005.Cooperative Learning Teori, Riset dan Praktik. Penerjemah : Nurulita. Bandung: Penerbit Nusa Media.

Somad, Permanarian dan Hernawati, Tati. 1996. Ortopedagogik Anak Tunarungu. Bandung: Departemen Pendidikan dan Kebudayaan Direktorat Jenderal Pendidikan Tinggi Proyek Pendidikan Tenaga Guru.

Sugiono. 2016. Metode Penelitian Pendidikan Pendekatan Kuantitatif, Kualitatif, dan R\&D. Bandung: Alfabeta.

Sugiyono. 2012. Statistika Untuk Penelitian. Bandung: Alfabeta. 
Surayya,dkk. 2014. "Pengaruh Model Pembelajaran Think Pair Share Terhadap Hasil Belajar IPA Ditinjau dari Ketrampilan Berpikir Kritis Siswa". E-Journal Program Pascasarjana Universitas Pendidikan Ganesha. Vol IV.

Trianto. 2010. Mengembangkan Model Pembelajaran Tematik. Jakarta: PT Prestasi Putrakaraya

Warsono dan Hariyanto. 2012. Pembelajaran Aktif Teori dan Asesmen. Bandung: PT Rosdakrya.

Wasita, Ahmad.2012. Seluk-Beluk Tunarungu \& Tunawicara Serta Strategi Pembelajaran. Jogjakarta: Javalitera

Tim Penyusun. 2014. Pedoman Penulisan Skripsi Universitas Negeri Surabaya. Surabaya: UNESA University Press.

Depdikbud. Permendikbud no 67 tahun 2013 Tentang Kerangka Dasar dan Struktur Kurikulum Sekolah Dasar/Madrasah Ibtidaiyah

Dekdikbud. Permendikbud no 24 tahun 2016 Kompetensi Inti dan Kompetensi Dasar Matematika SD/MI 